\title{
Correction to: Surgical management of complex ileocolonic Crohn's disease: a survey of IBD colorectal surgeons to assess variability in operative strategy
}

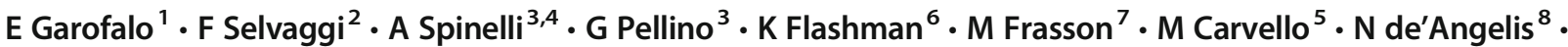 \\ A Garcia-Granero ${ }^{9} \cdot$ M Harper $^{10} \cdot$ J Warusavitarne $^{11} \cdot$ M Coleman $^{12} \cdot$ E Espin $^{13} \cdot$ V Celentano $^{10,14}$ (D)
}

Published online: 7 May 2021

(C) The Author(s) 2021

\section{Correction to: International Journal of Colorectal Disease https://doi.org/10.1007/s00384-021-03892-z}

In the original published version of this article, the co-author correct A Spinelli's affiliation has been added in the list of affiliations.

The original article has been corrected.
Open Access This article is licensed under a Creative Commons Attribution 4.0 International License, which permits use, sharing, adaptation, distribution and reproduction in any medium or format, as long as you give appropriate credit to the original author(s) and the source, provide a link to the Creative Commons licence, and indicate if changes were made. The images or other third party material in this article are included in the article's Creative Commons licence, unless indicated otherwise in a credit line to the material. If material is not included in the article's Creative Commons licence and your intended use is not permitted by statutory regulation or exceeds the permitted use, you will need to obtain permission directly from the copyright holder. To view a copy of this licence, visit http://creativecommons.org/licenses/by/4.0/.

Publisher's note Springer Nature remains neutral with regard to jurisdictional claims in published maps and institutional affiliations.

7 Department of General Surgery, Colorectal Unit, La Fe University and Polytechnic Hospital, University of Valencia, Valencia, Spain

8 Department of Digestive Surgery, Assistance Publique Hôpitaux de Paris, Henri Mondor Hospital, Université Paris-Est (UEP), Créteil, France

9 Colorectal Surgery, Hospital Universitario Son Espases, Palma de Mallorca, Spain

10 University of Portsmouth, Portsmouth, UK

11 Department of Colorectal Surgery, St Mark's Hospital, Harrow, Middlesex, UK

12 Department of Colorectal Surgery, University Hospitals Plymouth NHS Trust, Plymouth, UK

13 Department of General Surgery, Hospital Valle de Hebron, Universitat Autonoma de Barcelona, Barcelona, Spain

14 Department of Surgery and Cancer, Imperial College, London, UK 